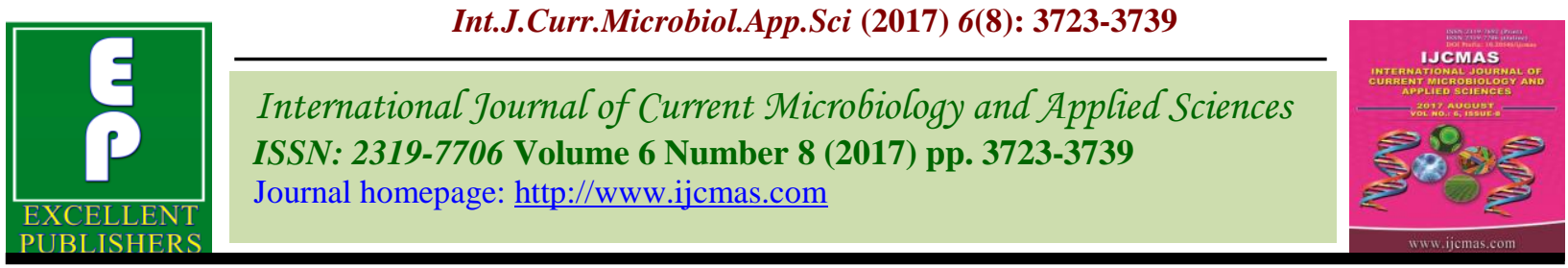

Original Research Article

https://doi.org/10.20546/ijcmas.2017.608.450

\title{
Phytoecological Characterization of the Spontaneous Oleaginous of the Congolese Forest
}

\author{
Victor Kimpouni*, Ghislain Bileri Bakala and Josérald Chaîph Mamboueni
}

Ecole normale supérieure, université Marien Ngouabi, B.P. 237, Brazzaville, Congo
*Corresponding author

Keywords

Congo, Floristic

diversity, Biofuel,

Congolese forest,

NWFP,

Phytoecology.

Article Info

Accepted:

21 June 2017

Available Online:

10 August 2017

\section{A B S T R A C T}

The study of the potential of Congo's spontaneous flora in biofuel resources is based on the parameters of ecological structure. 11 species $(22.9 \%)$ are present on the 48 main retained by PROTA 14 . The spatial distribution of the species shows that only the Bétou UFA gathers all the species. The best represented in the different forest areas are Ongokea gore, Pentaclethra eetveldeana, Pentaclethra macrophylla and Pycnanthus angolensis. Except for the Conkouati-Douli National Park, the Lossi Sanctuary and the Aubeville Forest, where there are some peculiarities, these species are characterized by low densities ranging from 0.001 to 5 individuals.ha- 1 and basal areas generally less than $1 \mathrm{~m}^{2}$.ha- 1 . The diametric structure is on the whole erratic type, marker of insufficient regeneration. Phytoecological data reveal that this forest cannot support sustained industrial exploitation in the production of second-generation biofuels. These species, which constitute an energy source for the disseminating agents, are $73 \%$ nutritive and $82 \%$ phytotherapeutic to humans. These multi-purpose species are at the same time of interest to the wood and craft industries, while being non-timber forest products of prime choice.

\section{Introduction}

Located in central Africa, the Congo is covered by $60-65 \%$ rainforest and $35-40 \%$ savannah (Vennetier, 1977; Hecketsweiler, 1990). Forest cover accounts for about $12 \%$ of the Congo Basin forests; equivalent to about 10\% of tropical forests (IUCN, 1996; Hecketsweiler, 1990; FAO, 2005). The Congolese forest is divided into three discontinuous blocks of unequal size, both in size and floristic diversity (IUCN, 1996; Kimpouni et al., 2013a). The northern Congo block, by far the most luxuriant and diversified, covers a dry facies (31\%) and a flooded (20\%). Those of the south-Congo developed on the mainland and were distributed as follows: the Mayombe (3\%) and the Chaillu (11\%). Congolese forests, particularly in southern Congo, have been exploited since the 1920s for: (i) dam construction, (ii) bridges, and (iii) locomotive boiler feed until 1957, when Fuel oil replaces solid fuels (Cusset, 1989). Until 1972, logging was the first support of the Congolese economy before being supplanted by oil. Studies show that Congolese populations derive substantial benefits by exploiting 
floristic diversity. The most profitable aspects are ethnobotany linked to the traditional pharmacopoeia, food, crafts and phytochemistry. The issue associated with biofuels is new and almost unknown.

The surge in oil prices and the problems of pollution caused by the use of fossil and nonrenewable energies, the exploitation of biofuels is a global deal with multiple benefits. Biofuels are defined as fuels produced from non-fossil organic materials derived from biomass that complement or substitute fossil fuels. Depending on the origin of the biomass used and the processing processes, biofuels are classified in three generations [(i) biofuels produced exclusively from crops (first generation); (ii) biofuels resulting from oilseeds (second generation) and (iii) biofuels of algal origin known as algae fuels (third generation)] and two sectors (alcohol and oil and derivatives).

Currently, only the first generation of biofuels has reached the industrial stage. In comparison to fossil fuels, biofuels have the advantage of being less polluting, renewable and inexhaustible if they are managed sustainably (Raven et al., 2010). However, their disadvantages include: (i) the allocation of the best agricultural land, and (ii) the conversion of several hectares of forest for settlement. The dreaded consequences are: (i) occupation of arable land, (ii) food insecurity and famine, and (iii) population migration. Despite the negative aspects, the biofuel sectors are developing more and more everywhere in the world. This is the case in Europe, where consumption of biofuels increased by more than $3 \%$ between 2010 and 2011. From 13.2 million tons of oil equivalent in 2010 to 13.6 million tons of oil equivalent in 2011, an increase of $3 \%$.

In tropical Africa, more than 250 species of oilseeds are identified and used for their oil, but only $65(26 \%)$ are suitable for this purpose. The tests of a second-generation biofuel operation selected 48 (19\%) species with proven potential (Grace et al., 2009). In the Congo, if the biofuel sector is not yet developed, Ouamba et al., (1985) report that Congolese flora has a non-negligible wealth of oil-bearing species capable of producing biofuels. However, there are no studies to determine the behaviour of the biofuel resources species within the Congolese flora. The characterization of the phytoecological parameters of the said taxa is the basis of this study.

The objectives of this study focus on improving the knowledge of Congo flora by: (i) inventorying the second generation biofuel resources species of the Congolese flora; (ii) characterization of phytoecological data for each taxa; (iii) estimating the potential of the Congolese forest for a sustained and rational industrial exploitation of second-generation biofuels

\section{Materials and Methods}

\section{Presentation of the study site}

Stretching between latitudes $4^{\circ}$ North and $5^{\circ}$ South and longitudes $11^{\circ}$ and $19^{\circ}$ East (Figure 1), the Congo straddles the equator and covers $342000 \mathrm{~km}^{2}$ (Vennetier, 1977; Sy et al., 2008). Located in Central Africa, it is bordered by the Central African Republic to the north, Cameroon to the northwest, Gabon and the Atlantic Ocean to the west, the Democratic Republic of Congo to the east and south-east, Angolan enclave of Cabinda in the South (Vennetier, 1977).

The climate is a wet equatorial type with three variants: (i) equatorial climate in the northern part, characterized by abundant rainfall throughout the year, with peaks oscillating from 1600 to $2000 \mathrm{~mm} /$ year; (ii) subtropical 
in the center, the characteristics of which are (i) a dry season of 1 to 3 months, (ii) precipitation between 1600 and $1800 \mathrm{~mm}$ (Vennetier, 1977); (iii) low-Congolese climate in the south-west, characterized by moderate rainfall and a very marked dry season (June to September) framed by two rainy periods, the most abundant from February to May. The precipitations vary between 1200 and $1700 \mathrm{~mm}$ (M.E.F.E, $2012 \mathrm{~b}$ ). It is characterized by an average annual temperature of about $25^{\circ} \mathrm{C}$. The thermal amplitudes do not exceed $5^{\circ} \mathrm{C}$ during the year. This climate is marked by (i) a dry and cool season from June to September and (ii) a warm and humid rainy season from October to June with a very pronounced slowdown in precipitation between January and February (Vennetier, 1977).

\section{Soils}

Congo soils are generally ferralitic, poor in exchangeable bases and highly permeable due to the sandy substrate which facilitates the migration of soil solutions (Vennetier, 1977; Denis, 1970). According to Denis (1970), these soils are divided into four main classes: hydromorphic soils, podzols, poorly developed soils and ferralitic soils.

\section{Vegetation and flora}

The forest formations have a floristic composition dominated by Fabaceae, Malvaceae, Rubiaceae and Euphorbiaceae (White, 1986; Kimpouni, 1993). Dense and clear forests on land develop in the Mayombe and Kouilou regions (150,3172 hectares, or $6.69 \%$ of Congolese forests), (ii) in Chaillu $(4,386,633$ hectares, or $19.52 \%$ of forest cover), (iii) Upper Sangha (7,500,000 hectares, or 33\% of Congo's total forests); The flooded forests of Lower Sangha $(85,000,000$ hectares, or $38 \%$ of Congolese forests); Forests, galleries and forest mosaics
$(589,862$ hectares, or $2.63 \%$ of Congo's forests) are developing in the Plateaux, the Pool and the Bouenza. The savannahs, mainly in the south of the equator, are interspersed with forest groves and galleries. They are divided into three zones of unequal importance: the Plateau of the Cataracts, the Niari Valley and the large Batéké itself heterogeneous (Diafouka, 1997).

\section{Congolesechorology}

The territory of the Republic of Congo is included in the regional center of GuineoCongolese endemism (White, 1986). Inspired by the subdivision of Descoings (1975), Kimpouni et al., (1992) integrated this territory into the African chorological system of White (1979, 1986). Eleven phytogeographical districts grouped into six sectors; three domains and two regions are recognized. Congolese forests are mainly located in the (i) Mayombe (Mayombian forests) phytogeographical districts; (ii) Chaillu (Chaillu forest); (iii) Upper Sangha and Lower Sangha (Congo northern forest).

\section{Materials}

The base of the biofuel source species is the inventory of PROTA 14. Taxa whose samples are absent from the herbarium, their certification in the Congolese flora is based on data from the literature; this is the case of Irvingia wombulu Vermoesen. This activity not only confirmed the existence of biofuel source species of the Congolese spontaneous flora; But also to establish their geographical distribution.

The material is based on specimens of spontaneous oilseed plants collected in Congolese forests and deposited in the national herbarium (IEC) located at the IRSEN; of our own floristic inventories (Youbi, Lossi, Aubeville), the compilation of 
forest management inventory data from forest concessions (BétouUFA, MissaUFA, MokabiDzangaUFA, LopolaUFA, IpendjaUFA, Loundoungou-ToukoulakaUFA, KaboUFA, PokolaUFA, NgombéUFA, Pikounda NordUFE) and protected areas (Odzala National Park, Conkouati-Douli National Park), the Makany (1976) phytosociological surveys in the plateaux Téké forest (Figure 1).

The analysis of the labels of the 39 herbarium samples representing 10 species reveals that: (i) 12 are harvested in the Mayombe forest; (ii) seven from the forests of the Mayama area; (iii) 3 from the Moutampa forest; (iv) two collected from the Gamboma forest islets; (v) 15 samples collected from the Congolese forest, one specimen per locality: Zanaga forest, forest on the Kinkala road, $17 \mathrm{~km}$ from Brazzaville, Frigniagbe forest (French Guinea), Bomassa forest, gallery of BanzaNgedi (Brazzaville), forest at Mabombo, forest at N'douo ferry, forest block at Inoni cliff, forest at Divinié, forest gallery near Edou, forest on Mayéyé road, Ngo forest block, Forest north of the IEC concession, Mandombé forest (Boko), gallery at Loufoulakari falls.

\section{Methods}

The study method is based on two complementary approaches: bibliographic compilation, on the one hand, and (i) the use of forest inventory data for management plans and (ii) accessible floristic surveys.

\section{Bibliographic compilation}

The bibliographic compilation allowed the state of place of taxa source of biofuel, the spontaneous flora Congolese. It is based on the work of Makany (1976), Sita and Moutsambote (1988), Hecketsweiler and Mokoko-Ikonga (1991), Nzinga (1992), Van Asbroeck et al., (1997), Kimpouni (2006), Kimpouni et al., (2008), M.E.F.E (2003a, 2003b, 2004, 2006, 2007, 2008a, 2008b, 2010a, 2010b, 2011, 2012).

\section{Using data from accessible management plans and accessible plant records}

The data result from the UFAs which have been the subject of a multi-resource inventory for a management plan on the one hand, and on the other hand of all accessible plant works. For example, in the forest zone (i) in the northern Congo, the combined data come from the UFAs Betou (300,000 ha), Missa (225,500 ha), Mokabi-Dzanga (370,000 ha), Lopola (199,900 ha), Ipendja, LoudoungouToukoulaka (552,676 ha), Kabo (267,048 ha), Pokola (377,550 ha), Ngombé $(13,500,289$ ha), Pikounda North UFE (93,970 ha), Odzala-Kokoua National Park Sanctuary of Lossi (35,000 ha); (ii) Cataracts, the floristic data of the Aubeville forest (1.5 ha); (iii) the Mayombe and the Congolese littoral, the data are those of the GREFE on the Aucoumeaklaineana forest (4 ha), and in the Conkouati-Douli National Park (504,950 ha)the survey is about 6 ha.

\section{Ecological parameters monitored}

The phytoecological parameters identified for each species are density, diametric structure, basal area, relative frequency, relative density, relative abundance and mean overlap, type of diaspora and ecological group.

The frequency of taxa is equal to the number of surveys where the taxon is present;

The relative frequency is equal to the number of surveys where the taxon is present relative to the total number of surveys;

The relative density is equal to the density of the taxon by the total density of the taxa;

Index of diversity is equal to the number of species of the family by the total of the species of the survey; 
The density expresses the number of individuals of a species per unit area. It allows not only to assess the contribution of each species in the forest sectors, but also to compare them whatever the size of the areas inventoried (Puig, 2001);

Basal area is the area of trunks projected on the ground. It allows us to better appreciate the spatial areas occupied by the trunks of a species in a given ecosystem, but also to estimate the production capacity of a species (White and Edwards, 2001; Mbou, 2009);

The diametric structure makes it possible to assess the regeneration capacity of these species within the forest (Peters, 1997; Puig, 2001);

Relative abundance is the number of individuals of a species relative to the total number of individuals in a given ecosystem. It makes it possible to form an idea of the rank occupied by each species in relation to the others, in the different forests;

The average coverage is the projection on the ground of the air cover of an individual. It allows appreciating the surface of all the aerial part of the individual, in order to have an idea of the productive capacity of the latter.

\section{Results and Discussion}

\section{Floristic diversity}

From 48 main spontaneous oilseeds of the tropical flora, 11 are present in forest formations in the Congo, 23\% (Table 1 and Appendix 1).

They are distributed in 7 families of which Irvingiaceae is the most diversified with 3 species.

\section{Phytoecological data}

\section{Frequency and densities}

The frequency of the present taxa varies from 17.65 to $94.12 \%$; the relative frequency oscillates from 2.56 to $13.68 \%$; the relative density is between 9.09 and $27.27 \%$. The best represented species are Pentaclethra macrophylla, Pycnanthus angolensis and Ongokea gore. The most prominent families are Irvingiaceae (27.27\%), Fabaceae and Clusiaceae with $8.18 \%$ each.

Among all the taxa, Pentadesma butyracea and Irvingia wombulu would be the least present in the Congolese forest. These taxa combine the weakest phytoecological data (frequency, relative frequency and relative density).

\section{Relative abundance}

The biofuel resources species are less abundant in the forest formations of the Congo (Table 2). The Lopola forest, taken as an example, reveals a relative abundance ranging from 0.84 to $2.82 \%$. Total recovery in the UFA is $7.59 \%$. Panda oleosa is the most abundant species and one that supports the recovery of species resources in biofuel.

\section{Density data for taxa}

From one forest type to another, the density of the different taxa is very variable without being high.For all forest formations, they range from 5.5 to 0.17 trees.ha ${ }^{-1}$.

\section{Kouilou district}

In the Youbi forest the densities vary from 1 to 1.7 tree.ha $^{-1}$, for an average of $1.08 \pm 0.35$ tree.ha ${ }^{-1}$.Conkouati-Douli national park, the density of biofuel source species varies from 4 to 35 trees.ha ${ }^{-1}$, an average of $21 \pm 4.09$ 
trees $\mathrm{ha}^{-1}$. This density is associated with Pentaclethra eetveldeana with an average of $16.6 \pm 5.44$ trees.ha $^{-1}$.

\section{Niari District}

In the Aubeville forest, densities range from 0.7 to 13.3 trees.ha ${ }^{-1}$, or $5.5 \pm 1.95$ trees. ha ${ }^{-1}$ on average.

\section{Upper Sangha District}

\section{Likouala forest}

Ipendja UFA, the densities of species biofuel resources vary according to forest types. (i) in the dense hardwood forest, the density varies from 0.01 to 0.37 trees.ha $^{-1}$ and an average of $0.30 \pm 0.11$ trees.ha $^{-1}$; (ii) in light forest, it oscillates from 0.01 to 0.39 trees.ha $^{-1}$, that is to say an average of $0.32 \pm 0.08$ tree. $^{-1}{ }^{-1}$; (iii) in the flooded forest, the density is between 0.001 and 0.71 , with an average of $0.24 \pm$ 0.07 tree $^{-1} \mathrm{ha}^{-1}$.

Loundoungou-ToukoulakaUFA, the stem density $10 \leq \mathrm{dbh}<70 \mathrm{~cm}$, is as follows: (i) in the southern mixed forest the densities vary from 0.001 to 2.32 trees.ha $^{-1}$, or $1.14 \pm 0.35$ trees.ha $^{-1}$ on average; (ii) in the forest at Gilbertiodendron dewevrei (Limbali) they range from 0.03 to 1.13 trees.ha $^{-1}$ and $0.42 \pm$ 0.18 trees.ha $^{-1}$ on average; (iii) they range from 0.5 to 1.94 trees.ha ${ }^{-1}$, with an average of $1.05 \pm 0.20$ trees.ha $^{-1}$ in the northern mixed forest.

The data for the Betou, Missa, MokabiDzanga and Lopola UFAs are collected according to two classes of dbh. The class of $20 \leq \mathrm{dbh}<50 \mathrm{~cm}$ : (i) in the Betou UFA the densities are between 0.01 and 0.65 for an average of $0.25 \pm 0.05$ tree.ha $^{-1}$; (ii) in the Missa UFA, they are between 0.01 and 0.48 tree. $\mathrm{ha}^{-1}$ and the mean is $0.17 \pm 0.05$ tree. $^{-1} \mathrm{a}^{-1}$; (iii) in the Mokabi-Dzanga forest, densities oscillate from 0.01 to 0.55 tree.ha $^{-1}$ for an average of $0.44 \pm 0.13$ tree.ha $^{-1}$; (iv) and at Lopola, densities range from 0.001 to 0.74 tree.ha ${ }^{-1}$ and an average of $0.31 \pm 0.06$ tree.ha $^{-}$ ${ }^{1}$. As for the trees $\mathrm{dbh} \geq 50 \mathrm{~cm}$, (i) the density in the Betou forest is from 0.05 to 2.08 tree.ha ${ }^{-1}$ for an average of $0.7 \pm 0.14$ tree.ha $^{-1}$ ; (ii) they are between 0.02 and 1.49 tree. $^{-1}$, an average of $0.44 \pm 0.12$ tree.ha $^{-1}$, in the Missa forest; (iii) in Mokabi-Dzanga, densities range from 0.01 to 1.62 tree. $^{-1} a^{-1}$ and an average of $0.71 \pm 0.22$ tree.ha $^{-1}$; (iv) and in the Lopola forest, they range from 0.001 to 1.53 tree.ha $^{-1}$, or $0.45 \pm 0.16$ tree. $^{-1}$ on average.

\section{Sangha forest}

In PokolaUFA, global densities range from 0.27 to 1.22 tree. $^{-1}$ and the mean is $0.60 \pm$ 0.12 tree.ha $^{-1}$. However, they are expressed according to the forest types and according to two classes of diameter of $\mathrm{dbh}$, for the dense and clear forests. The trees of $20 \leq \mathrm{dbh}<50$ $\mathrm{cm}$, (i) in dense forest the densities oscillate from 0.05 to 1.07 tree.ha $^{-1}$ for an average of $0.59 \pm 0.15$ tree.ha $^{-1}$; (ii) in clear forests, they range from 0.22 to 1.02 tree.ha $^{-1}$ with an average of $0.62 \pm 0.11$. As for dbh trees $\geq 50$ $\mathrm{cm}$, densities range from 0.27 to 1.51 tree. $^{-1}$ for an average of $0.59 \pm 0.17$ tree.ha $^{-1}$, in dense forest; in the clear forest, they oscillate from 0.21 to 1.21 tree $^{-1} \mathrm{ha}^{-1}$ and the mean is $0.58 \pm 0.12$ tree.ha $^{-1}$; (iii) in the forest at Gilbertiodendron dewevrei (Limbali) the densities range from 0.28 to 1.42 tree. $^{-1}{ }^{-1}$ for an average of $0.82 \pm 0.13$ tree.ha $^{-1}$; (iv) in the Marantaceae forest, densities range from 0.04 to 0.34 tree.ha $^{-1}$, the mean is $0.20 \pm 0.04$ tree.ha ${ }^{-1} ;(\mathrm{v})$ and in the flooded forest, they range from 0.29 to 1.97 tree.ha $^{-1}$, or $0.97 \pm$ 0.21 tree $^{-1} \mathrm{ha}^{-1}$ on average.

In KaboUFA, densities range from 0.01 to 0.76 trees.ha $^{-1}$ and the mean is $0.39 \pm 0.13$ tree.ha ${ }^{-1}$. 
In the NgombéUFA: for the trees of $20 \leq \mathrm{dbh}$ $<50 \mathrm{~cm}$, the densities are between 0.24 and 1.37 tree. $^{-1} \mathrm{a}^{-1}$ and an average of $0.58 \pm 0.14$ tree.ha ${ }^{-1}$; For trees of $\mathrm{dbh} \geq 50 \mathrm{~cm}$, densities range from 0.11 to 0.63 tree.ha $^{-1}$, or $0.27 \pm$ 0.05 tree. $^{-1} \mathrm{r}^{-1}$ on average.

In the Pikounda north UFE, densities oscillate from 0.1 to 1.54 tree $^{-1} \mathrm{ha}^{-1}$ for an average of $0.83 \pm 0.27$ tree $^{-1} \mathrm{ha}^{-1}$.

\section{West Cuvette Forest}

In the Lossi forest, trees of $10 \leq \mathrm{dbh}<70 \mathrm{~cm}$ have densities between 0.4 and 6.8 trees.ha $^{-1}$ for an average of $2.18 \pm 0.99$ trees.ha $^{-1}$; for trees of $\mathrm{dbh} \geq 70 \mathrm{~cm}$, they oscillatefrom 0.4 to 0.8 tree.ha $^{-1}$, or $1.4 \pm 1.04$ tree.ha $^{-1}$ on average.

\section{Basal area}

The projection of the trunk surface of the biofuel resource species shows that all have low forest area occupancy. For all forest formations, the basal area varies from 0.27 to $1.83 \mathrm{~m}^{2} \cdot \mathrm{ha}^{-1}$. Individually, the basal area of taxa does not reach $1 \mathrm{~m}^{2} \cdot \mathrm{ha}^{-1}$.

Within the different UFA forests and elsewhere, the maximum basal area covered by biofuel resources is $1.83 \mathrm{~m}^{2} . \mathrm{ha}^{-1}$, at best.

In the Likouala forest area, the projected area of trunks on the ground, of biofuel resources, ranges from 1.04 to $1.78 \mathrm{~m}^{2} . \mathrm{ha}^{-1}$. Pentaclethra macrophylla is the species that bears this basal area.

The basal area of the species, (1) in the BetouUFA, ranges from 0.001 to $0.39 \mathrm{~m}^{2} \cdot \mathrm{ha}^{-1}$, for a total of $1.78 \mathrm{~m}^{2} \cdot \mathrm{ha}^{-1}$; (2) in the MissaUFA, basal area varies from 0.001 to $0.30 \mathrm{~m}^{2} \cdot \mathrm{ha}^{-1}$ against a total of $1.04 \mathrm{~m}^{2} \cdot \mathrm{ha}^{-1}$; (3) it ranges from 0.001 to $0.31 \mathrm{~m}^{2} \cdot \mathrm{ha}^{-1}$ in the Mokabi-Dzanga UFA, compared with a total basal area of $1.24 \mathrm{~m}^{2} \cdot \mathrm{ha}^{-1}$; (4) the basal area in the Lopola UFA forest varies from 0.001 to $0.36 \mathrm{~m}^{2}$.ha $\mathrm{h}^{-1}$ whereas it is $1.33 \mathrm{~m}^{2} \cdot \mathrm{ha}^{-1}$ for all taxa; (5) in the Ipendja UFA, the basal area varies from 0.001 to $0.5 \mathrm{~m}^{2} \cdot \mathrm{ha}^{-1}$ for a total of $0.86 \mathrm{~m}^{2} . \mathrm{ha}^{-1}$ overall. (i) It ranges from 0.001 to $0.22 \mathrm{~m}^{2} \cdot \mathrm{ha}^{-1}$ in the dense forest and is 0.65 $\mathrm{m}^{2} \cdot \mathrm{ha}^{-1}$ for all taxa; (ii) from 0.001 to 0.1 $\mathrm{m}^{2} \cdot \mathrm{ha}^{-1}$ for a total basal area of $0.54 \mathrm{~m}^{2} \cdot \mathrm{ha}^{-1}$ in the swamp forest; (iii) from 0.001 to 0.18 $\mathrm{m}^{2} \cdot \mathrm{ha}^{-1}$ for a total basal area of $0.51 \mathrm{~m}^{2} \cdot \mathrm{ha}^{-1}$ in the light forest; (6) in LoundoungouToukoulaka UFA, the basal area varies from 0.81 to $1.02 \mathrm{~m}^{2}$.ha ${ }^{-1}$ for a total of $1.83 \mathrm{~m}^{2}$.ha1 , in mixed mixed-land forest; It is between 0.06 and $0.21 \mathrm{~m}^{2} . \mathrm{ha}^{-1}$ and the total basal area is $0.27 \mathrm{~m}^{2} \cdot \mathrm{ha}^{-1}$ in the Limbali forest. The taxon carrying this basal area is Irvingia grandifolia.

In the Sangha forest, (i) the basal area is between 0.06 and $0.30 \mathrm{~m}^{2} \cdot \mathrm{ha}^{-1}$ against $1 \mathrm{~m}^{2} \cdot \mathrm{ha}^{-1}$ for all species of the Ngombé UFA; (ii) it is between 0.37 and $0.56 \mathrm{~m}^{2} \cdot \mathrm{ha}^{-1}$ and $0.93 \mathrm{~m}^{2} \cdot \mathrm{ha}^{-1}$ overall, in the Pikounda north UFE. The most prominent species is Panda oleosa.

In the Lossi forest, the basal area varies from 0.03 to $0.51 \mathrm{~m}^{2} \cdot \mathrm{ha}^{-1}$ and, on the whole, is 1 $\mathrm{m}^{2} \cdot \mathrm{ha}^{-1}$ for trees of $10 \leq \mathrm{dbh}<70 \mathrm{~cm}$. They range from 0.03 to $0.56 \mathrm{~m}^{2} \cdot \mathrm{ha}^{-1}$, or $1.2 \mathrm{~m}^{2} \cdot \mathrm{ha}^{-1}$ for all trees of $\mathrm{dbh} \geq 70 \mathrm{~cm}$.

In the Youbi forest, the basal area varies from 0.07 to $0.2 \mathrm{~m}^{2} \cdot \mathrm{ha}^{-1}$ per taxon and $0.4 \mathrm{~m}^{2} \cdot \mathrm{ha}^{-1}$ for the whole.

In the Conkouati-Douli National Park, the basal area is between 0.54 and $5.17 \mathrm{~m}^{2} \cdot \mathrm{ha}^{-1}$, an average of $3.57 \pm 2.63 \mathrm{~m}^{2} \cdot \mathrm{ha}^{-1}$. Pentaclethra eetveldeana is the species that occupies space better $\left(3.06 \pm 0.54 \mathrm{~m}^{2} \cdot \mathrm{ha}^{-1}\right)$.

\section{Diameter structure}

The diametric structure of the biofuel resources species in the Congolese forest illustrates poor recruitment within diameter 
classes (Figure 2). In the forests of Betou, Mokabi-Dzanga and Lopola, the diametric structure reveals a regenerative cohort, almost nonexistent. With some exceptions, the diametric structure denotes an erratic distribution.

Table.1 Distribution of taxa in different forest inventory areas

\begin{tabular}{|c|c|c|c|c|c|c|c|c|c|c|c|c|c|c|c|c|c|}
\hline \multirow{2}{*}{ Taxa } & \multicolumn{17}{|c|}{ Forest areas } \\
\hline & 1 & 2 & 3 & 4 & 5 & 6 & 7 & 8 & 9 & 10 & 11 & 12 & 13 & 14 & 15 & 16 & 17 \\
\hline \multicolumn{18}{|l|}{ Clusiaceae } \\
\hline $\begin{array}{l}\text { Allanblackia floribunda } \\
\text { Oliv. }\end{array}$ & + & + & + & - & - & + & + & - & - & + & - & - & + & + & - & + & + \\
\hline $\begin{array}{l}\text { Pentadesma } \\
\text { butyracea }(\mathrm{Sab} .) \text { Sabine }\end{array}$ & + & + & + & + & - & - & - & - & - & - & - & - & + & - & - & + & - \\
\hline \multicolumn{18}{|l|}{ Euphorbiaceae } \\
\hline $\begin{array}{l}\text { Ricinodendron heudelotii } \\
\text { (Baill.) Pierre ex Heckel }\end{array}$ & + & + & + & + & + & + & + & + & + & + & - & + & + & - & + & - & - \\
\hline \multicolumn{18}{|l|}{ Fabaceae } \\
\hline $\begin{array}{l}\text { Pentaclethra eetveldeana } \\
\text { De Wild. \& Th. Dur. }\end{array}$ & + & + & - & - & - & - & - & + & + & + & + & + & + & - & + & + & - \\
\hline $\begin{array}{l}\text { Pentaclethra macrophylla } \\
\text { Benth. }\end{array}$ & + & + & + & + & + & + & + & + & + & + & + & + & + & - & + & + & + \\
\hline \multicolumn{18}{|l|}{ Irvingiaceae } \\
\hline $\begin{array}{l}\text { Irvingia } \\
\text { gabonensis(Aubry- } \\
\text { Lecomte ex O’Rorke) }\end{array}$ & + & + & + & + & + & + & + & - & + & + & + & - & + & + & + & - & + \\
\hline $\begin{array}{l}\text { Irvingia grandifolia (Engl.) } \\
\text { Engl. }\end{array}$ & + & + & + & + & - & + & + & + & + & - & - & - & + & - & + & - & + \\
\hline $\begin{array}{l}\text { Irvingia } \\
\text { wombuluVermoesen }\end{array}$ & + & - & - & - & - & - & - & - & + & - & - & - & - & - & + & - & - \\
\hline \multicolumn{18}{|l|}{ Myristicaceae } \\
\hline $\begin{array}{l}\text { Pycnanthus angolensis } \\
\text { (Welw.) Exell. }\end{array}$ & + & + & + & + & + & + & + & + & + & + & + & + & + & - & + & + & + \\
\hline \multicolumn{18}{|l|}{ Olacaceae } \\
\hline Ongokea gore (Hua) Pierre & + & + & + & + & + & + & + & + & + & + & + & - & + & + & + & + & + \\
\hline \multicolumn{18}{|l|}{ Pandaceae } \\
\hline Panda oleosa Pierre & + & + & + & + & + & + & + & + & + & + & - & - & - & + & + & - & - \\
\hline
\end{tabular}

Legend: Presence (+); Absence (-); Bétou UFA (1); Missa UFA (2); Mokabi-Dzanga UFA (3); Lopola UFA (4); Ipendja UFA (5); Loundoungou-Toukoulaka UFA (6); Kabo UFA (7); Pokola UFA (8); Ngombé UFA (9);

Pikounda North UFE (10); Plateau Teke Forest (11); Aubeville Forest (12); Lossi forest (13); Youbi Forest (14); Odzala-Kokoua National Park (15); Conkouati-Douli National Park (16); Okoumé Forest of Mayombe (17).

Table.2 Relative abundance of biofuel resources species in PokolaUFA

\begin{tabular}{|c|c|c|c|c|c|c|}
\hline \multirow[b]{2}{*}{ Species } & \multicolumn{6}{|c|}{ Relative abundance $(\%)$ by types forest } \\
\hline & 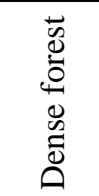 & 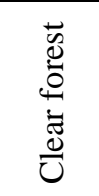 & 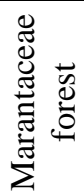 & 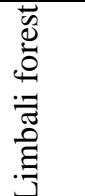 & $\begin{array}{l}\vec{d} \\
\frac{d}{0} \\
\frac{0}{0} \\
\frac{0}{L}\end{array}$ & 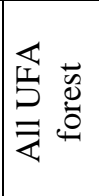 \\
\hline Panda oleosa & 5,14 & 4,81 & 1,40 & 3,10 & 3,99 & 2,82 \\
\hline Pentaclethra eetveldeana & 1,01 & 2,19 & 1,24 & 1,98 & 2,24 & 1,44 \\
\hline Pentaclethra macrophylla & 1,22 & 1,46 & 0,16 & 1,55 & 1,25 & 0,84 \\
\hline Pycnanthus angolensis & 2,10 & 2,1 & 0,47 & 1,68 & 1,72 & 1,18 \\
\hline Ricinodendron heudelotii & 2,71 & 2,71 & 0,78 & 0,61 & 0,59 & 1,31 \\
\hline Total recovery & 12,18 & 13,27 & 4,05 & 8,92 & 9,79 & 7,59 \\
\hline
\end{tabular}


Fig.1 Distribution of Congolese forest in UFA and location of forest inventories

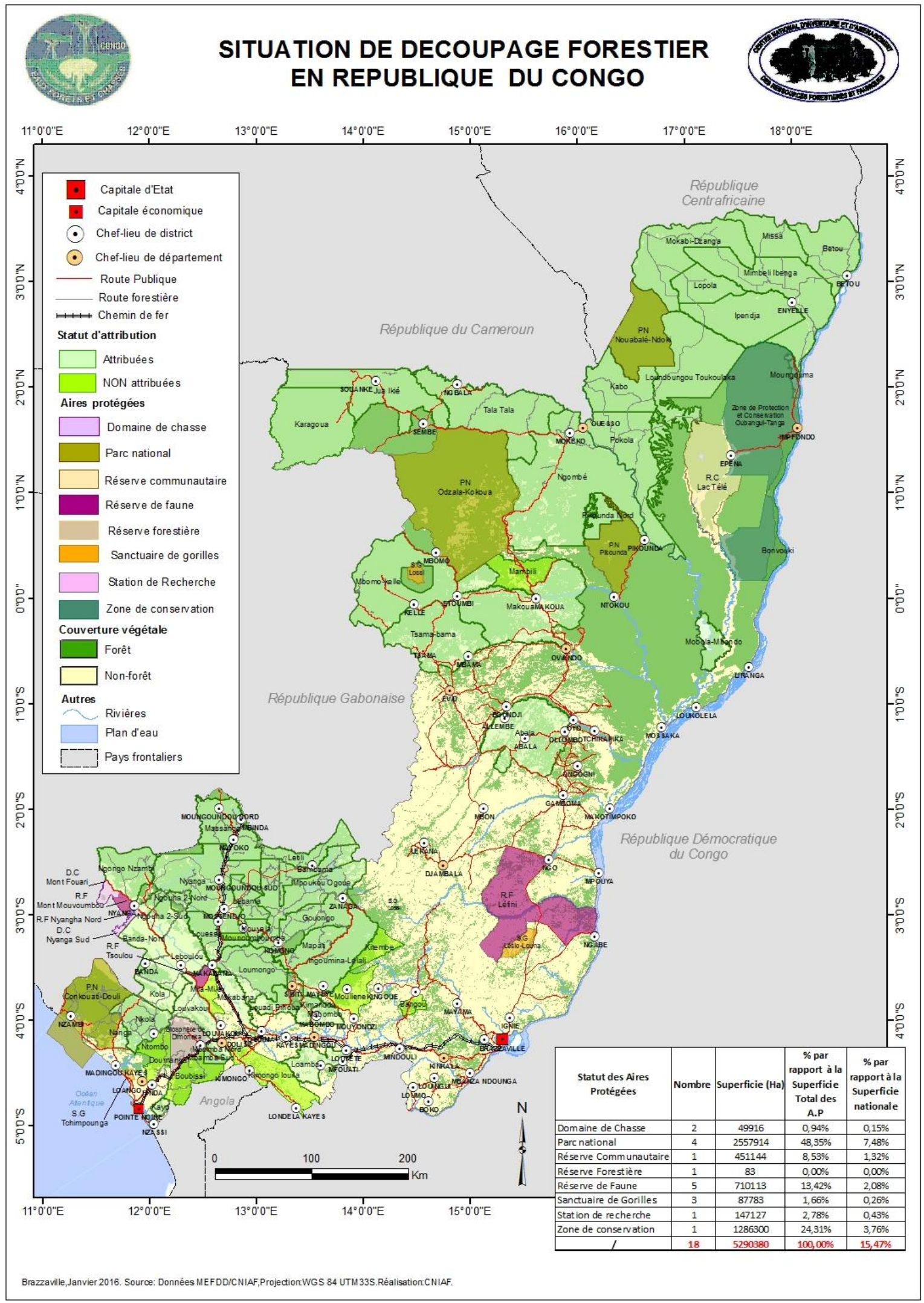


Fig.2 Diametric structure of the biofuel resources of the Congolese forest. Legend: Betou UFA (A), Missa UFA (B), Mokabi-Dzanga UFA (C), Lopola UFA (D), Ipendja UFA (E), Kabo) UFA,

Pikounda north UFE (I)

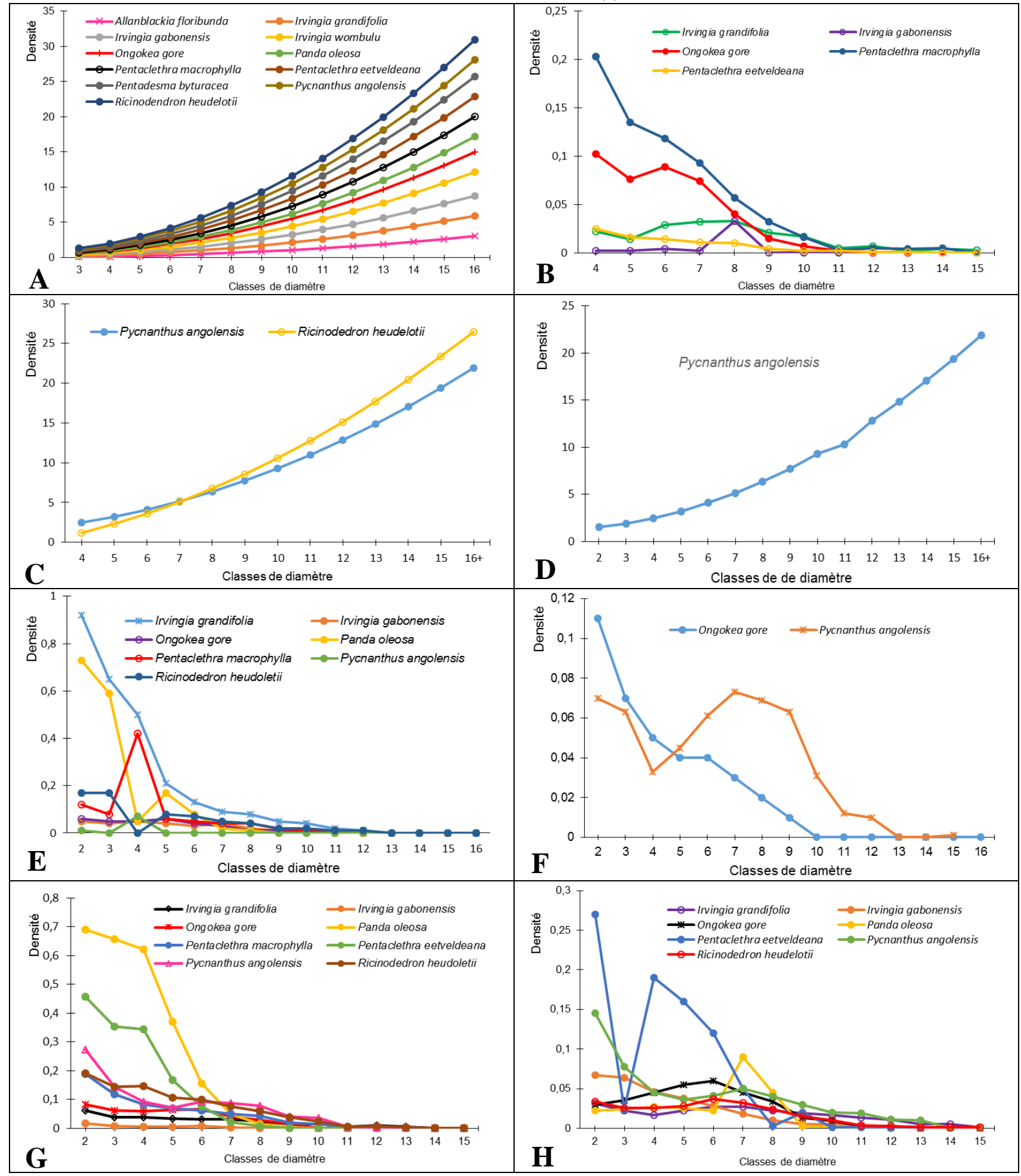




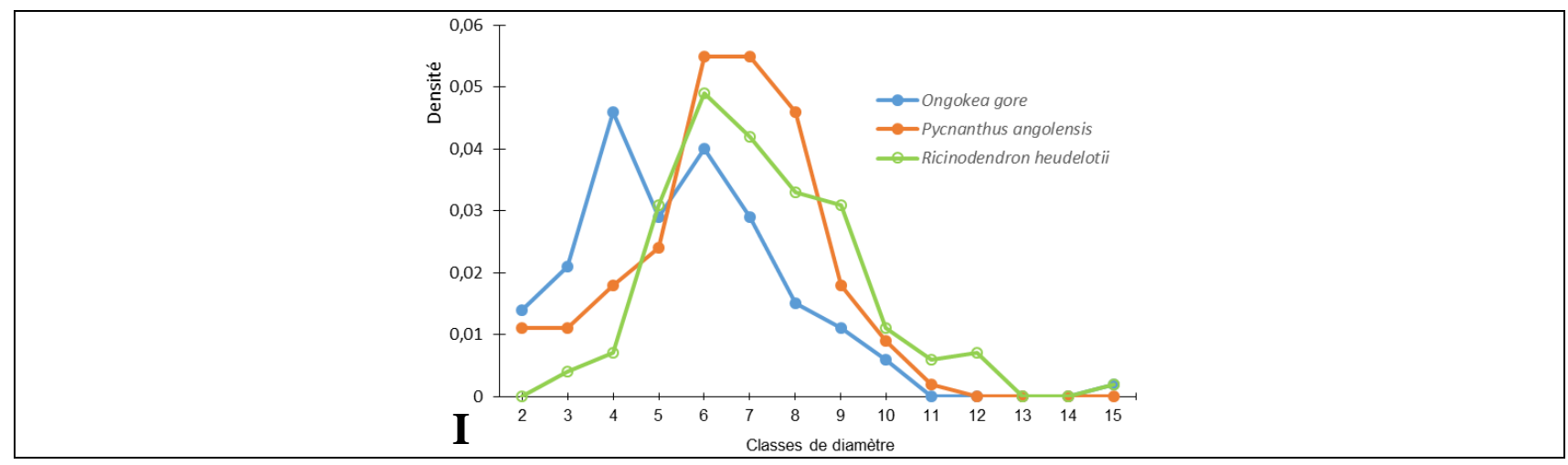

Appendix.1 Views of some specimens of spontaneous oilseeds of Congolese flora (Photo credits: Victor Kimpouni, except Irvingia gabonensis (Y. Issembe))

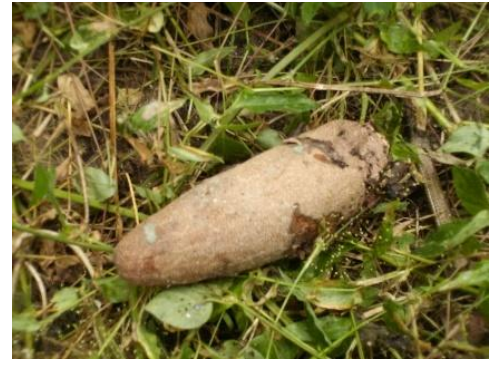

Allanblackia floribunda

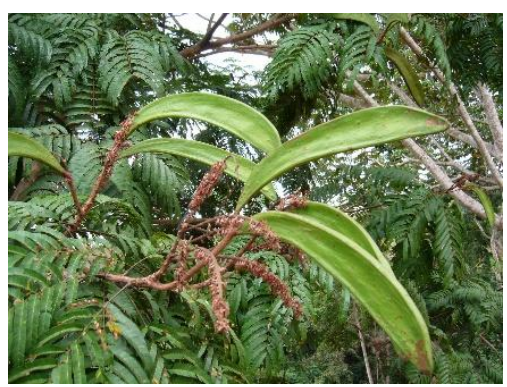

Pentaclethra eetveldeana

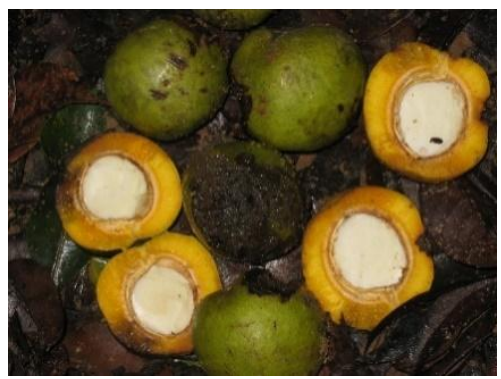

Irvingia gabonensis

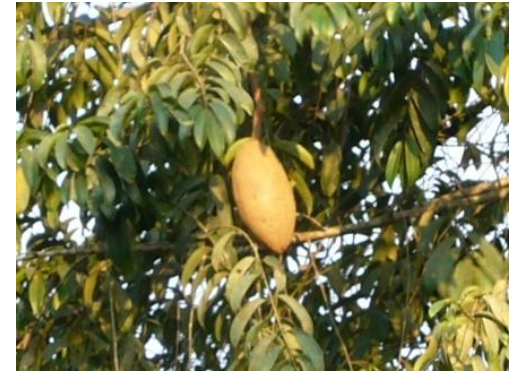

Allanblackia floribunda

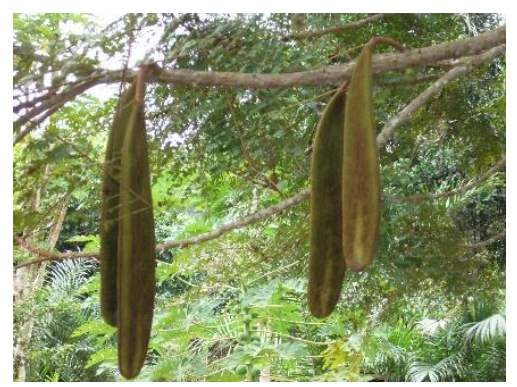

Pentaclethra macrophylla

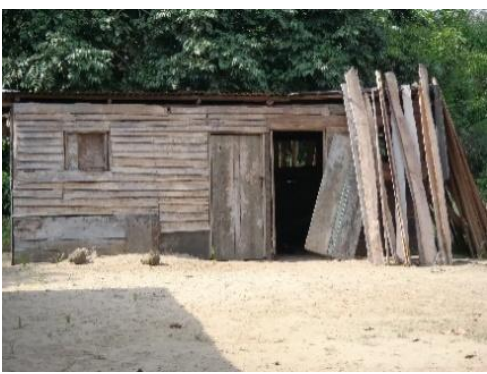

Pycnanthus angolensis

(planche éclatées)

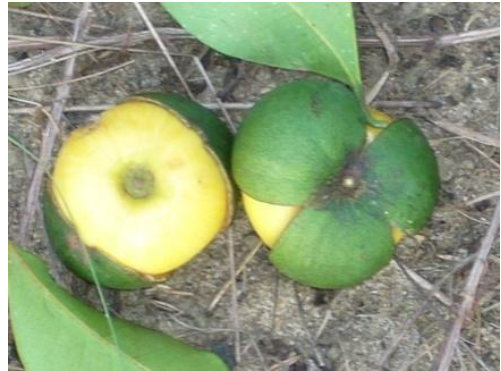

Ongokea gore

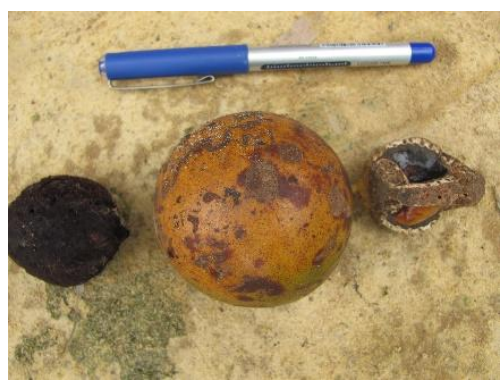

Panda oleosa

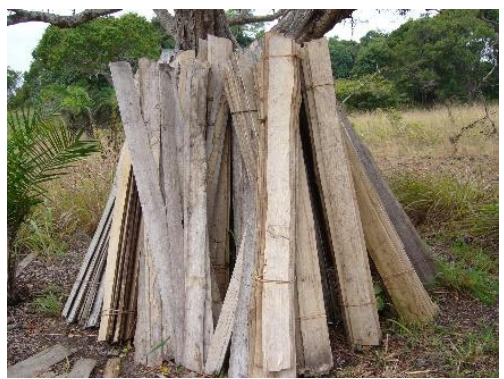

Pycnanthus angolensis

(planche éclatées) 


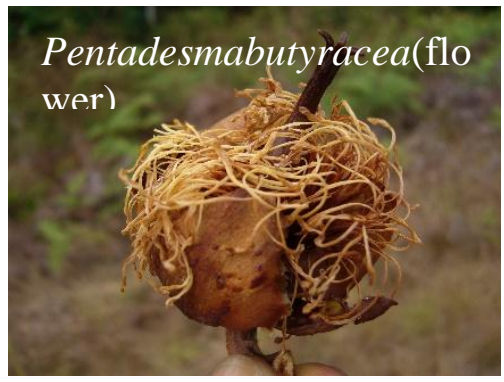

Pentadesma butyracea (Flower)

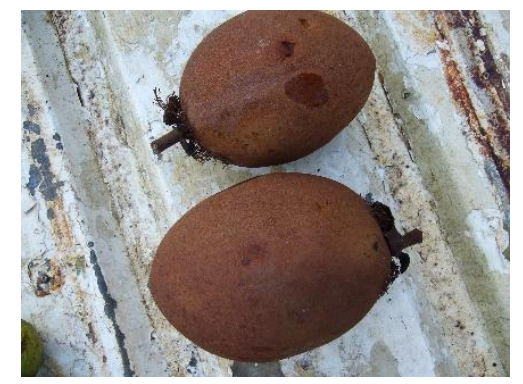

Pentadesma butyracea

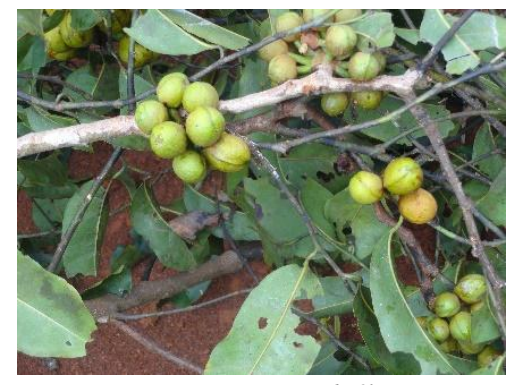

Irvingia grandiflora

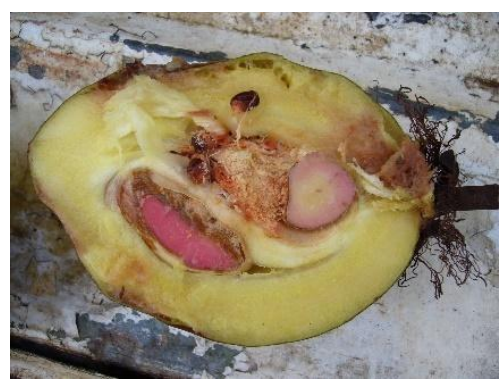

Pentadesma butyracea

\section{Analysis of plant diversity}

The spatial distribution of biofuel resource species shows that they are, to varying degrees, in all forestry facies. At the present stage of knowledge and floristic inventories, Missa and Bétou UFA shave the best potential in terms of biofuel resources, respectively 91 and $100 \%$ of the species. The absence of some species in other forest areas could be explained by insufficient inventory and / or harvesting, 39 samples of herbariums listed at the IEC for 10 species of biofuel resources (Manguila, 2009; Batangouna, 2010; Mambouéni-Mbika, 2012).

The analysis of the plant data shows a paucispecific and floristic Congolese forest in biofuel resources. 11 species out of 48 , let be (either) $23 \%$ of the main species retained in PROTA 14. Notwithstanding the low level of the specific diversity of biofuel resources within this forest ecosystem, these taxa have low densities. It is generally understood in all forest areas of 0.01 to 4 trees.ha $^{-1}$ of biofuel resources. Since the inventory analysis scale is the area covered by the UFA, taking account of forest types, the extrapolation of data does not make it possible to detect zone with biofuel resources. This observation is supported by small-scale floristic surveys. This is the case of the Lossi Sanctuary where Pentaclethra macrophylla is 6.8 trees.ha $^{-1}$, Aubeville forest where Pentaclethra eetveldeana and Pycnanthus angolensis have 5.3 and 13.3 trees.ha $^{-1}$, respectively Conkouati reserve where some species have densities that reach 19 or even 27 trees.ha ${ }^{-1}$. These values corroborate the data of Mitani et al., (1994) in the Lopé reserve in Gabon where the densities of these species biofuel resources range from 0.2 to 9 trees.ha $^{-1}$. Taking into account their low representativeness in Congolese forests $(0.16$ to $5.14 \%$ ), these species of biofuel resources can not characterize these ecosystems. The rain forests of Central Africa with densities ranging from 265 to 427 trees.ha $^{-1}$ show a predominance of Fabaceae, Rubiaceae, Euphorbiaceae (Kimpouni et al., 2008, 2013, 2014; Puig, 2001). The basis for these low densities is the non-gregarious behavior of these taxa within Congolese forests (Nzinga, 1992). 


\section{Ecological data}

The analysis of the diametric structure of the biofuel resources species reveals that none shows good regeneration and/or a satisfactory occupation of the environment. Indeed, no curve has the appearance of an "inverted L or J", synonymous with satisfactory natural regeneration (Peters, 1997; Puig, 2001; White and Edwards, 2001; Mbou, 2009). According to Peters (1997), "Such a structure represents a population whose regeneration is limited for one reason or another with the difficulties of installing new seedlings". Finally, the erratic structure is explained by the fact that the planting of new seedlings is sporadic or irregular (Peters, 1997). Taking into account the ecological groups of Moutsamboté (2012), this bad regeneration could be explained by the existence of heliophiles and sciaheliophiles. They are therefore subjected to an energy competition that ensures the selection of species most often at the juvenile stage (Polunin, 1967; White, 1986; Adriens, 1993).

In spite of the structural data that are not adequate for the emergence of a biofuel sector focusing on the spontaneous flora of the Congolese forest, these taxa associate a low production of fruits. Indeed, (i) the diameter of the trunk proportionally correlated with the size of the crown, and (ii) the crown diameter affects the amount of fruit produced (Bouchon et al., 1989; Bourden, 2013). This relationship reveals that the higher basal area, no tree bears branches and ipso factothe fruit (Bouchon et al., 1989; White and Edwards, 2001; Bourden, 2013).

These biofuel resources are also an energy source for frugivorous animals. Besides Pentaclethra eetveldeana and Pentaclethramacrophylla with ballochores diaspores, the other nine taxa are sarcochores. However, the work of Van Der Pijl (1969) and Alexander (1978) showed that the Sarcochore is a food source for animals, mainly large mammals, such as the elephant, which ensure dissemination. Today, several sources mention the threat of extinction of elephants in the Central African subregion. The corollaries of this threat weigh on the future of loxodontochore species, biofuel resources of Congolese forests.

\section{Wood industry and endogenous knowledge}

Except for Pycnanthus angolensis and Ricinodendron heudelotii, targeted by the timber industry, all species of biofuel resources are of interest to the sawmill and craft industry. Notwithstanding the timber supply chain, all species have ethnobotanical applications by local and indigenous populations (Bouquet, 1969; Adjanohoun et al., 1988; Hecketsweiler and Mokoko-Ikonga, 1991; Profizi et al., 1993; Raponda-Walker and Sillans, 1961; Miabangana, 1998; Tamio Matondo, 2003). Riparian populations derive substantial direct and indirect benefits by exploiting various organs, both vegetative and regenerative. They are a source of therapeutics, food, income generation, crafts, etc. (Profizi et al., 1993; Raponda-Walker and Sillans, 1961). Non-timber forest products (NWFPs) in the sub-region include Irvingia gabonensis, Irvingia sp. and Ricinodendron heudelotii, even if the dietary use of the latter is not known. The generative organs at the center of this activity are highly sought after, which translates into high anthropogenic pressure on these species. By way of example: (i) the nutritional value of the seeds of Ricinodendron heudelotii is: $200 \mathrm{~g} \cdot \mathrm{kg}^{-1}$ of protein; 450 g. $\mathrm{kg}^{-1}$ of lipids; $250 \mathrm{~g} . \mathrm{kg}^{-1}$ of carbohydrates and 600 mg. $\mathrm{kg}^{-1}$ of calcium; (ii) almonds of Irvingia sp. have generated 5,488 direct jobs in Cameroon and over 250,000 indirect jobs with an annual income of US \$ 16.34 million (Ndoye et al., 2011). These NTFPs are traded locally, subregionally and internationally, as evidenced by the work of Tabuna (1999), Tchatat and Ndoye (2006) and Lescuyer (2010). 
All these activities, which are based on the collection of generative organs, severely impact the renewal of these taxa within ecosystems. In connection with the oilseed chain, strong anthropogenic pressure was exerted on Ongokea gore during the colonial period (Raponda-Walker and Sillans, 1961).

\section{Resources and industrial exploitation of second generation biofuels}

Is the Congolese forest likely to support an industry focused on the sustainable and rational management of second generation biofuel species? To answer this question, the phytoecological and ethnobotanical data of the biofuel resources species contribute to maintain that the Congolese forest does not lend itself to this exploitation. In fact, we have recorded a small number of biofuel species within this flora, and these in most cases combine weak phytoecological parameters (density, basal area, crown diameter, regeneration capacity and fruit productions). Thus, the maintenance of biofuel resources species in Congolese forests is acute. However, the seeds of these taxa are the basis for the possible production of second-generation biofuels. An industrial exploitation, while being the propagation organs, would inevitably lead to the disappearance of the said taxa unless cultivated (Peters, 1997).

In conclusion, Congolese forests are scarcely provided with biofuel resources as shown by phytoecological parameters, but this study shows the existence of pockets where the gregariousness of these taxa would be proved. Notwithstanding the induced effects of the agents of dissemination, anthropogenic action is that which more seriously impacts natural regeneration. This is all the more likely given the fact that, despite their low spatial representativeness, the multi-purpose character makes them highly sought after.
Many of them are first-rate NTFPs in meeting food, phytotherapeutic and income needs for local and indigenous populations. These reasons alone explain the high degree of anthropogenic impact on these species. Analysis of the data reveals that industrial exploitation, as a primary source of production of second-generation biofuels, would surely put these plants in danger of extinction within the Congolese forest.

\section{Acknowledgments}

We would like to thank Mr. Jean Albert NGOMA, Head of the Forest Inventory and Management Department, Ministry of the Forest Economy for Sustainable Development and Environment, for his frank collaboration.

\section{References}

Adjanohoun, E.J., A.M.R. Ahyi, L. Ake Assi, J. Baniakina, P. Chibon, G. Cusset, V. Doulou, A. Enzanza, J. Eyme, E. Goudote, E. Keita, C. Mbemba, J. Mollet, J.-M. Moutsambote, J. Mpati and Sita, P. 1988. Contribution aux études ethnobotaniques et floristiques en République Populaire du Congo: Médecine traditionnelle et pharmacopée. ACCT, Paris, P. 605

Adriens, A. 1993. Influence de quelques facteurs du milieu sur la dynamique de Salix aurita dans la réserve naturelle des Hautes-Fagnes (Belgique). Belg. Journ. Bot. 126 (1): 71-80.

Alexandre, D.Y. 1978. Le rôle disséminateur des éléphants en forêt de TaÏ, Côte d'Ivoire. Orstom, Abidjan, P. 72.

Batangouna, A.P. 2010. Etat de connaissance des Annonaceae de la République du Congo. Mémoire du CAPES,Université Marien Ngouabi, Brazzaville, Congo.

Bouchon, J., J.F.Dhôte and Lanier L. 1989. Réaction individuelle des hêtres (Fagus salvatica L.) d'âges divers à diverses intensités d'éclaircie. Ann. Sci. For. 46 (3): 251-259. 
Bouquet,A. 1969. Pharmacopée des Kota et des Téké, plantes médicinales et toxiques. Direction de la recherche de L'Orstom, Brazzaville, p. 52.

Bourden, C. 2013. Bilan sur les mesures de biomasse aérienne et de carbone en mangroves amazoniennes. Mémoire de Master, Université des Antilles et de Guyane, Kourou, P. 40.

Cusset, G. 1989. La flore et la végétation du Mayombe: Etat de connaissances, PNUD/UNESCO, PP 103-106.

Denis, B.1970. Les sols de la région de Brazzaville, ORSTOM, Brazzaville, p. 92.

Descoings, B. 1975. Les types morphologiques et biomorphologiques des espèces graminoïdes dans les formations herbeuses tropicales. Nat. Monspel., Sér. Bot. 25: 23-25.

Diafouka, A.J.P. 1997. Analyse des usages des plantes médicinales dans quatre régions du Congo-Brazzaville. Thèse de doctorat, Université Libre de Bruxelles, Bruxelles, Belgique.

Fao. 2005. Evaluation des ressources forestières mondiales (FRA) 2005. Rapports nationaux, Rome, P. 70.

Grace, O.M., D.J. Borus and Bosch C.H. 2009. Oléagineux de l'Afrique tropicale: Conclusions et recommandations basées sur PROTA 14: " Oléagineux ". Fondation PROTA, Wegeningen, PaysBas, P. 86.

Hecketsweiler, P. 1990. La conservation des écosystèmes forestiers du Congo. UICN, Gland, Suisse et Cambridge, Royaume Unis, P. 187.

Hecketsweiler, P., C. Doumenge and Mokoko Ikonga J., 1991. Le parc national d'Odzala, Congo. UICN/CCE, Gland, Suisse, P. 334.

Hecketsweiler, P. and Mokoko Ikonga, J.1991. La réserve de Conkouati: Congo le secteur sud-est. UICN, Gland, Suisse, P. 323.

Kimpouni V., 1993. Les Eriocaulaceae d'Afrique centrale (Congo, Zaïre, Burundi, Rwanda); étude taxonomique et phytogéographique. Thèse de doctorat, Université Libre de Bruxelles, Bruxelles, Belgique.

Kimpouni, V. 2006. Premières données sur la diversité floristique de la forêt d'Aubeville (Congo Brazzaville). Syst. Geogr. P1. 78: 47-62.

Kimpouni, V., J. Lejoly and Lisowski S. 1992. Les Eriocaulaceae du Congo. Fragm. Flor. Geobot. 37 (1): 127-145.

Kimpouni, V., J.Loumeto and Mizingou,J. 2008. Diversité floristique du faciès forestier à Aucoumea klaineana (okoumé) $\mathrm{du}$ littoral congolais. Acta Botanica Gallica. $\quad 155 \quad$ (3): $\quad 323-334$ http://dx.doi.org/10.1080/12538078.2008. 10516113

Kimpouni, V., J.J. Loumeto and Mizingou, J. 2008. Diversité floristique du peuplement ligneux de la forêt monodominante à Okoumé (Aucoumea klaineana P.) du littoral congolais. Ann. Univ. Marien Ngouabi. 9 ( $\mathrm{N}^{\circ}$ spécial): 8-20.

Kimpouni, V., J.P. Makita-Madzou and Motom, M.2007. Spécificités ethnoculturelles sur les produits d'Irvingia gabonensis et Irvingia spp. (Irvingiaceae) au Congo Brazzaville. Ann. M. Ngouabi. 8 (4): 5058.

Kimpouni, V., P. Mbou, E. Apani and Motom, M. 2014. Étude floristique des îlots forestiers naturels de la Patte d'Oie de Brazzaville, Congo, Acta Botanica Gallica. 161:1, 63-79. DOI: 10.1080/12538078.2013.870048

Kimpouni, V., P. Mbou, E. Apani and Motom, M. 2013. Floristic diversity and structural parameters of the Brazzaville Patte d'Oie forest, Congo. Open Journal of Ecology. 3 (8): 518-531. http://dx.doi.org/10.4236 /oje.2013.38061

Kimpouni, V., E. Apani and Motom, M. 2013. Analyse phytoécologique de la flore ligneuse de la Haute Sangha (République du Congo). Adansonia, sér. 3. 35 (1): 107-134. http://dx.doi.org/10.5252/a2013 n1a9

Lejoly, J. 1996. Biodiversité végétale dans le parc national d'Odzala (Congo). Agreco 
CTFT, Bruxelles, P. 127.

Lescuyer, G., 2010. Importance économique des produits forestiers non ligneux dans quelques villages du sud - Cameroun. Bois et forêt des tropiques. 304 (2): 1524.

M.E.F.E. 2003a. Plan d'aménagement de l'unité forestière d'aménagement Lopola. Tome 1, Brazzaville, P. 298.

M.E.F.E. 2003b. Ressources forestières de l'unité forestière d'aménagement de Pokola. Rapport d'inventaire d'aménagement, Brazzaville, P. 91.

M.E.F.E. 2004. Rapport d'inventaire d'aménagement de l'UFA Ngombé, Tome 3/3, Brazzaville, P. 342.

M.E.F.E. 2006. Plan d'aménagement de l'unité forestière d'aménagement de Kabo. Rapport d'inventaire multi ressource, Brazzaville, P. 95.

M.E.F.E. 2008a. Projet d'aménagement de l'unité forestière d'aménagement de Mokabi-Dzanga. Tome 1/4, Brazzaville, P. 349.

M.E.F.E. 2008b. Rapport d'inventaire d'aménagement de l'UFA Ipendja. Tome 1, Brazzaville, p. 116.

M.E.F.E. 2010a. Plan d'aménagement de l'unité forestière d'aménagement de Loundoungou-Toukoulaka. Rapport d'inventaire mutiressources, Brazzaville, P. 108.

M.E.F.E. 2010b. Projet d'aménagement de l'unité forestière d'aménagement Missa. P. 329.

M.E.F.E. 2011. Projet d'aménagement de l'Unité Forestière d'Aménagement Bétou. Rapport d'inventaire multi ressources (Tome 1/3), Brazzaville, p.147.

M.E.F.E. 2012a. Plant d'aménagement de l'unité forestière d'exploitation de Pikounda nord. Rapport d'inventaire multi ressources, Brazzaville, p. 87.

M.E.F.E. 2012b. Etablissement des tarifs de cubage de la zone Chaillu (UFE Gouongo, Massanga, Mpoukou-Ogooue et Nyanga). Rapport de l'étude dendrométrique $\mathrm{N}^{\circ} 2$, Brazzaville, P. 26.

Makany, L. 1976. Végétation des plateaux Téké
(Congo). Collection des travaux de l'Université de Brazzaville, Brazzaville, P. 301.

Mamboueni Mbika, G.E. 2012. Distribution phytogéographique des Meliaceae et Sapotaceae du Congo. Mémoire CAPES, Université Marien Ngouabi, Brazzaville, Congo.

Manguila, 2009. Analyse phytogéographique des espèces ligneuses des Fabaceae au Congo. Mémoire du CAPES, Université Marien Ngouabi, Brazzaville, Congo.

Mbou, P.2009. Structure et typologie des îlots forestiers naturelles de la patte d'Oie (Brazzaville). Mémoire du CAPES, Université Marien Ngouabi, Brazzaville, Congo.

Mitani, M., S. Kuroda and Tutin, C.E.G. 1994. Floral lists from five study sites of apes in the African tropical forests. Tropics. 3 (3/4):247-248.

Moutsambote, J.-M. 2012. Etude écologique, phytogéographique et phytosociologique du Congo septentrional (Plateau, Cuvette, Likouala, Sangha) République du Congo. Thèse d'État, Université Marien Ngouabi, Brazzaville, Congo.

Ndoye, O., M. Tadoum,A. Asseng Ze, J. Masuch and Tieguhong Chupezi J. 2011. Importance des produits forestiers non ligneux dans la lutte contre la pauvreté et la sécurité alimentaire en Afrique Centrale. Réunion GTBAC 11, FAO/ECOFAC, P. 24.

Nzinga, J.J.1992. Intérêt économique et aspects structuraux d'une forêt dense équatoriale: La forêt à Okoumé et ses savanes inclusives (Congo). Thèse de doctorat, Université de Rennes, Rennes, France.

Ouamba, J., D. Mampouya and Biyoko, S. 1985. Séminaire sur la valorisation des oléagineux et huiles essentielles du Congo. UNMG, Fac. Sciences, Brazzaville, P. 13.

Polunin, N.1967. Eléments de Géographie Botanique, Gauthier-Villars, Paris, P. 532.

Peters, C.M.1997. Exploitation soutenue des produits forestiers autre que le bois en 
forêt Tropicale humide: Manuel d'initiation écologique. BSP, Washington, P. 50 .

Puig, H. 2001. La forêt tropicale humide. Belin, Paris, P. 447.

Profizi, J.-P., J.-P. Makita-Madzou, J.C. Milandou, C.N. Karanda,M. Motomand Bitsindou, I. 1993. Ressources végétales non ligneuses des forêts du Congo. Plan d'Action Forestier Tropical du Congo (PAFT-Congo). Université Marien Ngouabi, Brazzaville, p. 67.

Raponda-Walker, A. and Sillans, R. 1995. Les plantes utiles du Gabon. Sépia, Paris, P. 614.

Ravene, P.H., L.R. Berg and Hassenzahl D.M. 2010. Environnement. De Boeck, $6{ }^{\text {ème }}$ ed., P. 700

Sita, P. and Moutsambote, J.-M. 1988. Catalogue des plantes vasculaires du Congo. CERVE, Brazzaville, P. 194.

Tabuna, H. 1999. Le marché des produits forestiers non ligneux de l'Afrique Centrale en France et en Belgique. ICOFOR, Sindangbarabg, P. 32.

Tamio Matondo, J.D.D. 2003. Inventaire ethnobotanique, étude chimique et pharmacologique des plantes médicinales utilisées au Congo contre les maladies infectieuses de la peau. Mémoire du CAPES, Université Marien Ngouabi, Brazzaville, Congo.
Tchatat, M. and Ndoye, O. 2006. Etude des produits forestiers non ligneux d'Afrique Centrale. Bois et forêts des tropiques. 288 (2): 27-39.

Uicn. 1996. L'atlas pour la conservation des forêts tropicales d'Afrique. Gland: Uicn.

Van Asbroeck P., L. Kouka and Lejoly, J. 1997. Les associations' végétales de ligneux dans la forêt à Marantaceae du parc national d'Odzala (Congo-Brazzaville). Colloque phytosociologique XXVII, ULB, Bruxelles, Belgique

Van Der Pijl L. 1969. Principles of dispersal in higher plants. Springer-verlag, BerlinHeidelberg-New York, P. 154.

Vennetier, P. 1977. Atlas de la république populaire du Congo. Edition Jeune Afrique, P. 64.

White, F. 1979. The taxonomy, ecology and chorology of African Ebenaceae: The Guineo - Congolian species. Bull. Jard. Bot. Nat. Belg. 48: 245-358.

White, F. 1986. La végétation de l'Afrique. Mémoire accompagnant la carte de la végétation d'Afrique, ORSTOM/ UNESCO/AETFAT, Paris, P. 383.

White, L. and Edwards A. 2001. Conservation en forêt pluviale africaine: Méthode de recherche. WCS, P. 456.

\section{How to cite this article:}

Victor Kimpouni, Ghislain Bileri Bakala and Josérald Chaîph Mamboueni. 2017. Phytoecological Characterization of the Spontaneous Oleaginous of the Congolese Forest. Int.J.Curr.Microbiol.App.Sci. 6(8): 3723-3739. doi: https://doi.org/10.20546/ijcmas.2017.608.450 